\title{
Correction to: Feminist Judgments Projects at the Intersection
}

\author{
Martha Gayoye ${ }^{1} \cdot$ Mateenah Hunter $^{2} \cdot$ Ambreena Manji $^{3} \cdot$ Miriam Matinda $^{4}$. \\ Sharifah Sekalala ${ }^{1} \cdot$ Rachna Chaudhary $^{5}$ - Laura Lammasniemi ${ }^{1}$. \\ Shreya Munoth ${ }^{6}$. Devyani Prabhat ${ }^{7}$. Jhuma Sen ${ }^{8}$. Gillian Black ${ }^{9}$. \\ Sharon Cowan ${ }^{9} \cdot$ Chloë Kennedy $^{9} \cdot$ Vanessa E. Munro ${ }^{1}$
}

Published online: 2 March 2021

(c) The Author(s) 2021

\section{Correction to: Feminist Legal Studies https://doi.org/10.1007/s10691-020-09428-0}

In the original publication of the article, errors in the production stages resulted in Vanessa Munro being listed as sole author. A note was subsequently added to recognise that, while Vanessa Munro acted as corresponding author, the article was jointly authored by the following members of the African, Indian and Scottish Feminist Judgment Projects: Martha Gayoye, Mateenah Hunter, Ambreena Manji, Miriam Matinda, Sharifah Sekalala, Rachna Chaudhary, Laura Lammasniemi, Shreya Munoth, Devyani Prabhat, Jhuma Sen, Gillian Black, Sharon Cowan, Chloë Kennedy and Vanessa Munro. The correct citation and attribution of the article should be as co-authored by all those named as contributors to the dialogue.

Open Access This article is licensed under a Creative Commons Attribution 4.0 International License, which permits use, sharing, adaptation, distribution and reproduction in any medium or format, as long as you give appropriate credit to the original author(s) and the source, provide a link to the Creative Commons licence, and indicate if changes were made. The images or other third party material in this article are included in the article's Creative Commons licence, unless indicated otherwise in a credit line to the material. If material is not included in the article's Creative Commons licence and your intended use is not permitted by statutory regulation or exceeds the permitted use, you will need to obtain permission directly from the copyright holder. To view a copy of this licence, visit http://creativecommons.org/licen ses/by/4.0/.

The original article can be found online at https://doi.org/10.1007/s10691-020-09428-0.

Vanessa E. Munro

V.Munro@warwick.ac.uk

Extended author information available on the last page of the article 
Publisher's Note Springer Nature remains neutral with regard to jurisdictional claims in published maps and institutional affiliations.

\section{Authors and Affiliations}

\section{Martha Gayoye ${ }^{1} \cdot$ Mateenah Hunter $^{2} \cdot$ Ambreena Manji $^{3} \cdot$ Miriam Matinda $^{4}$. Sharifah Sekalala ${ }^{1} \cdot$ Rachna Chaudhary $^{5}$ - Laura Lammasniemi ${ }^{1}$. Shreya Munoth ${ }^{6}$. Devyani Prabhat ${ }^{7}$. Jhuma Sen ${ }^{8}$. Gillian Black ${ }^{9}$. Sharon Cowan ${ }^{9} \cdot$ Chloë Kennedy $^{9} \cdot$ Vanessa E. Munro $^{1}$}

Martha Gayoye

M.Gayoye@warwick.ac.uk

Mateenah Hunter

mhunter-parsonage@sahrc.org.za

Ambreena Manji

ManjiA1@ cardiff.ac.uk

Miriam Matinda

matindamiriz@gmail.com

Sharifah Sekalala

Sharifah.Sekalala@warwick.ac.uk

Rachna Chaudhary

rachna@aud.ac.in

Laura Lammasniemi

Laura.Lammasniemi@warwick.ac.uk

Shreya Munoth

munoth.shreya@gmail.com

Devyani Prabhat

Devyani.Prabhat@bristol.ac.uk

Jhuma Sen

jsen@jgu.edu.in

Gillian Black

gillian.black@ed.ac.uk

Sharon Cowan

s.cowan@ed.ac.uk

Chloë Kennedy

chloe.kennedy@ed.ac.uk

1 School of Law, University of Warwick, Coventry CV4 7AL, UK

228 Wenning Street, Groenkloof, Pretoria 0181, South Africa

3 School of Law and Politics, Cardiff University, 2.20, Law Building, Museum Avenue, Cardiff CF10 3AX, UK

4 Tumaini University Makumira, USA-River, P.O. Box 55, Arusha, Tanzania

5 School of Human Studies, Ambedkar University Delhi, AUD Kashmere Gate Campus, Lothian Road, Kashmere Gate, Delhi 110006, India

6 Delhi, India 
7 University of Bristol Law School, Wills Memorial Building, Queen's Road, Bristol BS8 1RJ, UK

8 Jindal Global Law School, Sonipat Narela Road, Near Jagdishpur Village, Sonipat, Haryana, India

9 School of Law, University of Edinburgh, Old College, South Bridge, Edinburgh EH8 9YL, UK 